\title{
ANALISIS KELENGKAPAN PENGISIAN INFORMED CONSENT TINDAKAN BEDAH DI RUMAH SAKIT PERTAMINA BINTANG AMIN TAHUN 2018
}

\author{
Mardheni Wulandari, Hernowo Anggoro Wasono1, Sri Maria Puji Lestari1, Ajeng \\ Nabilah Maitsya2
}

\begin{abstract}
1 Departemen Anatomi, Fakultas Kedokteran, Universitas Malahayati 2 Departemen Kedokteran Keluarga, Fakultas Kedokteran, Universitas Malahayati 3 Departemen Ilmu Kedokteran Komunitas, Fakultas Kedokteran, Universitas Malahayati 4 Program Studi Kedokteran, Fakultas Kedokteran, Universitas Malahayati
\end{abstract}

\begin{abstract}
Analysis Completeness of Informed Consent Surgery in Pertamina Bintang Amin Hospital December 2018. Informed Consent is an aggrement given by the patient or family to explanation the act of medical/surgical to perform on the patient and this informed consent must be complete. To find out the analysis completeness of Informed Consent surgery in Pertamina Bintang Amin Hospital December 2018. Quantitative research which descriptive design. Population in this research is all sheet of informed consent of major surgery elective. Data collection using observation of checklist. Technique data analysis was conducted using univariate statistic test. The result of the study of 100 informed consent sheets, percentage was most found completed on item name and dob/g as much as 56 sheets (56\%). In the important report component informed was found completed on item basic diagnosis 95 sheets (95\%) and consent was found on item name recipient $81(81 \%)$. In the Authentication component completed on item sign recipient 100 sheets $(100 \%)$. Conclusion on the whole sheets of informed consent completeness as much as $23 \%$.
\end{abstract}

Keyword: completeness, informed cinsent, surgery.

\begin{abstract}
Abstrak: Analisis Kelengkapan Pengisian Informed Consent Tindakan Beedah di Rumah Sakit Pertamina Bintang Amin Tahun 2018. Informed Consent adalah persetujuan yang diberikan pasien atau keluarga atas dasar penjelasan mengenai tindakan medik/operasi yang akan dilakukan terhadap pasien dan informed consent ini harus lengkap. Untuk mengetahui analisis kelengkapan pengisian informed consent tindakan bedah di Rumah Sakit Pertamina Bintang Amin Bandar Lampung Periode Desember tahun 2018. Jenis penelitian kuantitatif dengan rancangan descriptive. Populasi dalam penelitian ini adalah seluruh lembar informed consent tindakan bedah mayor elektif terencana. Pengambilan data menggunakan daftar tilik. Teknik analisis data dilakukan dengan menggunakan uji statistik univariat. Hasil penelitian dari 100 lembar informed consent, persentase kelengkapan tertinggi ditemukan pada item nama dan TTL/JK sebanyak 56 lembar $(56 \%)$. Pada komponen laporan penting kelengkapan informasi ditemukan pada item dasar diagnosa sebanyak 95 lembar (95\%) dan persetujuan ditemukan pada item nama penerima sebanyak 81 lembar (81\%). Pada kelompok Autentifikasi kelengkapan ditemukan pada item TTD penerima sebanyak 100 lembar (100\%). Kesimpulan secara keseluruhan lembar informed consent yang memenuhi kelengkapan sebanyak $23 \%$.
\end{abstract}

Kata Kunci: Kelengkapan, Informed Consent, Tindakan Bedah.

\section{PENDAHULUAN}

Sehat merupakan suatu hal yang diinginkan dalam kehidupan setiap orang, dengan hidup sehat maka setiap orang dapat menjalankan aktivitas sehari - hari sehingga kesehatan merupakan kebutuhan dasar yang sangat penting untuk 
diperhatikan setiap orang. Kesehatan sangat erat sekali hubungannya dengan rumah sakit. (Menkes, 2008)Menurut WHO (World Health Organization), rumah sakit adalah bagian integral dari suatau organisasi soaial dan kesehatan dengan fungsi menyediakan pelayanan paripurna (konperehensip), penyembuhan penyakit (kuratif) dan pencegahan penyakit (preventif) kepada masyarakat (WHO, 2008). UndangUndang Republik Indonesia No 44 Tahun 2009 tetang rumah sakit bahwa rumah sakit mempunyai kewajiban memberikan pelayanan kesehatan yang aman, bermutu, anti diskriminasi, dan efektif dengan mengutamakan kepentingan pasien sesuai dengan standar pelayanan rumah sakit (Menkes, 2008)

Terkait dengan pemenuhan hak pasien, dimana peningkatan mutu pelayanan kesehatan menjadi isu utama dalam pembangunan kesehatan baik dalam lingkup nasional maupun global. Pemenuhan hak pasien menjadi hal mutlak yang harus diperhatikan dalam tata laksana pelayanan kesehatan yang berkualitas. Jadi manalah mungkin seorang tenaga kesehatan yang juga manusia dapat memenuhi dengan sempurna seluruh kriteria kasus yang ada, sedangkan setiap orang sudah pasti "having their own limit". Oleh karena itu, selain untuk menjaga kemungkinan terlantarnya pasien oleh tenaga kesehatan yang mempunyai pasien banyak, atau terlantarnya tenaga kesehatan karena harus menghadapi tuntutan hanya karena tidak mengkomunikasikan kemungkinan penyakit maka dibuatlah suatu perjanjian hitam di atas putih antara tenaga kesehatan dengan pasien. Ini disebut sebagai "Informed Consent" (Hatta, 2011).

Informed consent bukan hanya merupakan masalah hukum saja, tetapi juga masalah etika sebab sesuai dengan prinsip autonomy atau prinsip kebebasan (Soekidjo, 2010). Pada pelaksanaan tindakan medis, masalah etik dan hukum perdata, tolak ukur yang digunakan adalah "kesalahan kecil", sehingga jika terjadi kesalahan kecil dalam tindakan medis yang merugikan pasien, maka sudah dapat dimintakan pertanggungjawabannya secara hukum. Hal ini disebabkan pada hukum perdata secara umum berlaku adegium " barang siapa merugikan orang lain harus memberikan ganti rugi", oleh karena itu adanya kesalahan kecil (ringan) pada pelaksanaan tindakan medis belum dapat dipakai sebagai tolak ukur untuk menjatuhkan sanki pidana (Soekidjo, 2010).

Salah satu untuk membangun suatu perjanjian atau persetujuan antara dokter dengan pasien harus adanya suatu tindakan medis salah satunya adalah tindakan bedah. Tindakan bedah atau operasi adalah semua tindakan pengobatan yang menggunakan cara invasif dengan membuka atau menampilkan bagian tubuh yang akan ditangani. Pembukaan tubuh ini umumnya dilakukan dengan membuat sayatan. Setelah bagian yang akan ditangani ditampilkan dilakukan tindakan perbaikan yang akan diakhiri dengan penutupan dan penjahitan luka. (Syamsuhidajat, 2010)

$$
\text { Pada Akhir tahun } 2013
$$
terdapat kasus yang menimpa seorang dokter obgen dipidana karena dalam melakukan tindakan medis tidak mengisi formulir persetujuan secara lengkap. Jika syarat Informed Consent tidak terpenuhi, maka tindakan medis tidak sah/ tidak legal untuk dilakukan. Formulir Informed Consent lupa dimintakan tanda tangan pasien/ keluarga pasien berarti pasien dan atau keluarga pasien tidak diberitahukan terdahulu tindakan medis yang dilakukan. Persetujuan tertulis dalam bentuk Informed consent mutlak dibutuhkan, dengan mengingat bahwa ilmu kedokteran bukanlah ilmu pasti, maka keberhasilan tindakan kedokteran bukan pula suatu kepastian, melainkan dipengaruhi oleh banyak faktor yang dapat berbeda-beda dari 
satu kasus ke kasus lainnya. Sebagai masyarakat yang beragama, perlu juga disadari bahwa keberhasilan tersebut ditentukan oleh izin Tuhan Yang Maha Esa. Dewasa ini pasien mempunyai pengetahuan yang semakin luas tentang bidang kedokteran, serta lebih ingin terlibat dalam pembuatan keputusan perawatan terhadap diri mereka. Karena alasan tersebut, persetujuan yang diperoleh dengan baik dapat memfasilitasi keinginan pasien tersebut, serta menjamin bahwa hubungan antara dokter dan pasien adalah berdasarkan keyakinan dan kepercayaan. (Naili, Sumarni, 2014).

\section{METODE}

Penelitian ini menggunakan jenis penelitian kuantitatif dengan rancangan deskriptif. Penelitian ini dilakukan di ruang rekam medis Rumah Sakit Pertamina Bintang Amin pada bulan Maret 2019. Sampel penelitian berjumlah 100 lembar. Analisis data menggunakan daftar tilik.

HASIL DAN PEMBAHASAN
Penelitian dilakukan di ruang rekam medis Rumah Sakit Pertamina Bintang Amin Bandar Lampung dan dilaksanakan bulan Maret 2019. Data diambil seluruh lembar informed consent tindakan bedah mayor elektif terencana ruang rekam medis di Rumah Sakit Pertamina Bintang Amin periode Desember tahun 2018.

Hasil Penelitian yang telah dilaksanakan di Rumah Sakit Pertamina Bintang Amin Bandar Lampung dengan melakukan observasi dan studi dokumentasi berkas rekam medis rawat inap yang ada lembar informed consent periode Desember 2018 yang diketahui bahwa dari 100 sampel berkas, peneliti melakukan analisis kelengkapan pengisian pada lembar informed consent berdasarkan komponen Analisis Identifikasi (identitas), Laporan yang penting, dan Autentikasi (tanda tangan).

1. Kelengkapan Pengisian Identifikasi Pasien

Hasil penelitian kelengkapan pengisian identifikasi pasien digambarkan dalam tabel berikut ini:

Tabel 1. Kelengkapan Identifikasi Pasien

\begin{tabular}{llllllll}
\hline No & Item & \multicolumn{2}{l}{ Kelengkapan } & & Total & \% \\
\cline { 3 - 8 } & & Ya & \% & Tidak & \% & & \\
\hline 1 & Nama & 56 & 56 & 44 & 44 & 100 & 100 \\
2 & TTL/ JK & 56 & 56 & 44 & 44 & 100 & 100 \\
3 & No RM & 47 & 47 & $\mathbf{5 3}$ & $\mathbf{5 3}$ & 100 & 100 \\
4 & Alamat & 55 & 55 & 45 & $\mathbf{4 5}$ & 100 & 100 \\
\hline Rata & Rata & $\mathbf{5 3 , 5 \%}$ & $\mathbf{4 6 , 5 \%}$ & & \\
\hline
\end{tabular}

Berdasarkan tabel di atas diketahui bahwa pada komponen identifikasi (identitas) pasien persentase yang paling tinggi kelengkapan pengisian ditemukan pada item nama dan TTL/JK sebanyak 56 lembar $(56 \%)$, dan rata-rata kelengkapan sebesar 53,5\%. Sedangkan persentase yang paling tinggi ketidaklengkapan pengisian ditemukan pada item no RM sebanyak 53 lembar (53\%) dan rata- rata ketidaklengkapan sebesar $46,5 \%$.
Berdasarkan hasil analisis didapatkan seluruh item belum dapat terisi lengkap sehingga hasil penelitian tersebut kurang sesuai dengan Permenkes RI No.129 Tahun 2008 bahwa dengan rekam medis yang lengkap adalah rekam medis (termasuk informed consent) yang telah diisi lengkap dalam waktu $<24$ jam setelah pelayanan rawat jalan atau setelah pasien inap diputuskan untuk pulang dengan standar pengisian $100 \%$ terisi, yang meliputi identitas pasien, anamnesis, rencana 
asuhan, pelaksanaan asuhan, tindak lanjut dan resume.

\section{Kelengkapan Pengisian Laporan Yang Penting}

Tabel 2. Kelengkapan Laporan yang Penting
Hasil penelitian kelengkapan pengisian laporan yang penting digambarkan dalam tabel berikut ini :

\begin{tabular}{|c|c|c|c|c|c|c|c|}
\hline \multirow[t]{2}{*}{ No } & \multirow[t]{2}{*}{ Item } & \multicolumn{4}{|c|}{ Kelengkapan } & \multirow[t]{2}{*}{ Total } & \multirow[t]{2}{*}{$\%$} \\
\hline & & $\mathbf{Y a}$ & $\%$ & Tidak & $\%$ & & \\
\hline \multicolumn{8}{|c|}{ Informasi } \\
\hline 1 & Nama Dokter & 89 & 89 & 11 & 11 & 100 & 100 \\
\hline 2 & Pemberi & 30 & 30 & 70 & 70 & 100 & 100 \\
\hline 3 & Penerima & 4 & 4 & 96 & 96 & 100 & 100 \\
\hline 4 & Diagnosis & 94 & 94 & 6 & 6 & 100 & 100 \\
\hline 5 & Dasar Diagnosis & 95 & 95 & 5 & 5 & 100 & 100 \\
\hline 6 & Tindakan & 89 & 89 & 11 & 11 & 100 & 100 \\
\hline 7 & Indikasi & 93 & 93 & 7 & 7 & 100 & 100 \\
\hline 8 & Tata Cara & 85 & 85 & 15 & 15 & 100 & 100 \\
\hline 9 & Tujuan & 85 & 85 & 15 & 15 & 100 & 100 \\
\hline 10 & Resiko & 80 & 80 & 20 & 20 & 100 & 100 \\
\hline 11 & Komplikasi & 80 & 80 & 20 & 20 & 100 & 100 \\
\hline 12 & Prognosis & 25 & 25 & 75 & 75 & 100 & 100 \\
\hline 13 & Alternatif & 22 & 22 & 78 & 78 & 100 & 100 \\
\hline \multicolumn{8}{|c|}{ Persetujuan } \\
\hline 14 & Hubungan dengan Pasien & 62 & 62 & 38 & 38 & 100 & 100 \\
\hline 15 & Nama Penerima & 81 & 81 & 19 & 19 & 100 & 100 \\
\hline 16 & TTL/JK & 78 & 78 & 22 & 22 & 100 & 100 \\
\hline 17 & Alamat & 74 & 74 & 26 & 26 & 100 & 100 \\
\hline \multicolumn{2}{|c|}{ Rata Rata } & & & & $1.5 c$ & & \\
\hline
\end{tabular}

Berdasarkan tabel di atas diketahui bahwa pada komponen laporan penting persentase yang paling tinggi kelengkapan pengisian kelompok informasi ditemukan pada item dasar diagnosa sebanyak 95 lembar (95\%), kelompok persetujuan ditemukan pada item nama penerima sebanyak 81 lembar (81\%) dan rata-rata kelengkapan sebesar $68,5 \%$. Sedangkan persentase yang paling tinggi ketidaklengkapan pengisian kelompok informasi ditemukan pada item penerima sebanyak 96 lembar (96\%), kelompok persetujuan ditemukan pada item hubungan dengan pasien sebanyak 38 lembar $(38 \%)$ dan rata- rata ketidaklengkapan sebesar $31,5 \%$.
Hal ini menunjukkan masih kurang diperhatikannya dalam pengisian pada kelompok laporan penting oleh dokter ataupun perawat. Dokter tidak memberikan informasi pada item informasi dan resiko sehingga pasien belum sepenuhnya mengetahui sesuatu yang terjadi setelah dilakukan operasi. Dari hasil penelitian tersebut menunjukkan bahwa tingkat keterisian belum mencapai $100 \%$. Hal ini tidak sesuai dengan Undang undang no.29 tahun 2004 penjelasan pada proses informed consent setidaknya harus meliputi diagnosis dan tata cara tindakan medis, tujuan tindakan medis, alternative lain dan resikonya, resiko dan komplikasi yang mungkin terjadi dan prognosisnya.

3. Kelengkapan Pengisian Autentikasi 
Hasil penelitian kelengkapan

penting

berikut

digambarkan dalam tabel pengisian autentikasi laporan yang

ini:

Tabel 3. Kelengkapan Autentikasi

\begin{tabular}{|c|c|c|c|c|c|c|c|}
\hline \multirow[t]{2}{*}{ No } & \multirow[t]{2}{*}{ Item } & \multicolumn{4}{|c|}{ Kelengkapan } & \multirow[t]{2}{*}{ Total } & \multirow[t]{2}{*}{$\%$} \\
\hline & & $\mathbf{Y a}$ & $\%$ & Tidak & $\%$ & & \\
\hline 1 & TTD Pemberi & 98 & 98 & 2 & 2 & 100 & 100 \\
\hline 2 & TTD Penerima & 96 & 96 & 4 & 4 & 100 & 100 \\
\hline 3 & Tanggal/jam & 87 & 87 & 13 & 13 & 100 & 100 \\
\hline 4 & TTD Penerima & 100 & 100 & 0 & 0 & 100 & 100 \\
\hline 5 & TTD Saksi 1 & 53 & 53 & 47 & 47 & 100 & 100 \\
\hline 6 & TTD Saksi 2 & 15 & 15 & 85 & 85 & 100 & 100 \\
\hline \multicolumn{2}{|c|}{ Rata Rata } & \multicolumn{2}{|c|}{$74,8 \%$} & & & & \\
\hline
\end{tabular}

Berdasarkan tabel di atas diketahui bahwa pada komponen autentifikasi persentase yang paling tinggi kelengkapan pengisian ditemukan pada item TTD penerima sebanyak 100 lembar $(100 \%)$, dan rata-rata kelengkapan sebesar $74,8 \%$. Sedangkan persentase yang paling tinggi ketidaklengkapan pengisian ditemukan pada item TTD saksi 2 sebanyak 85 lembar (85\%) dan rata- rata ketidaklengkapan sebesar 25,2\%. Sebaiknya item tanda tangan keluarga pasien, dan dokter yang merawat diisi dengan lengkap agar dapat dipertanggungjawabkan secara hukum serta sesuai dengan standar pelayanan minimal yang ada. Hal tersebut kurang sesuai dengan Permenkes RI

No.
290/MENKES/PER/III/2008 pasal 1 bahwa persetujuan tindakan kedokteran adalah persetujuan yang diberikan oleh pasien atau keluarga terdekat setelah mendapat penjelasan secara lengkap mengenai tindakan kedokteran atau kedokteran gigi yang akan dilakukan terhadap pasien sedangkan sesuai dengan pasal 3 yaitu setiap tindakan kedokteran yang mengandung risiko tinggi harus memperoleh persetujuan tertulis yang ditandatangani oleh yang berhak memberikan persetujuan.

4. Review Pencatatan

Hasil penelitian formulir informed Consent kelengkapan review pencatatan digamabrkan dalam tabel berikut ini :

\section{Tabel 4. Review Kelenggkapan pencatatan}

\begin{tabular}{lll}
\hline Keterangan & n & \% \\
\hline Informed Consent dengan kategori tidak lengkap (<80\% terisi) & 77 & $77 \%$ \\
Informed Consent dengan kategori lengkap ( $\geq 80 \%$ terisi) & 23 & $23 \%$ \\
\hline
\end{tabular}

Secara keseluruhan lembar informed consent yang terisi dengan lengkap atau $\geq 80 \%(\geq 22)$ adalah sebanyak 23 tabel daftar tilik dari 100 lembar isi format persetujuan tindakan medis operatif di Rumah Sakit Pertamina Bintang Amin periode Desember 2018. Sedangkan untuk

\section{KESIMPULAN}

Berdasarkan hasil analisis dan pembahasan penelitian, maka dapat keseluruhan lembar informed consent yang terisi tidak lengkap atau $<80 \%$ (<21) adalah sebanyak 77 tabel daftar tilik dari 100 lembar isi format persetujuan tindakan medis operatif di Rumah Sakit Pertamina Bintang Amin.

diambil kesimpulan mengenai Analisis kelengkapan Pengisian Informed Consent tindakan bedah di Rumah 
Sakit Pertamina Bintang Amin periode Desember tahun 2018 diperoleh kesimpulan sebagai berikut :

1. Pada komponen identifikasi (identitas) kelengkapan pengisian ditemukan pada item nama pasien sebanyak 56 lembar (56\%), Kelengkapan pengisian identifikasi rata- rata sebesar 53,5\%. Pada komponen laporan penting kelengkapan pengisian ditemukan pada item dasar diagnosa sebanyak 95 lembar (95\%), Kelengkapan pengisian laporan penting rata- rata sebesar $68,5 \%$. Pada komponen autentifikasi kelengkapan pengisian ditemukan pada item TTD penerima sebanyak 100 lembar $(100 \%)$, Kelengkapan pengisian autentifikasi ratarata sebesar $74,8 \%$.

2. Secara review keseluruhan lembar informed consent yang memenuhi kelengkapan sebanyak $23 \%$.

\section{DAFTAR PUSTAKA}

Hatta, Gemala R. (2011). Pedoman Manajemen Informasi Kesehatan Di Sarana

Pelayanan Kesehatan. Edisi Revisi , Jakarta: UIP.

Prof.Dr. Soekidjo Notoatmojo. (2010). Etika \& Hukum

Kesehatan. Jakarta :Rineka Cipta.

Konsil Kedokteran Indonesia. (2006). Manual Persetujuan

Tindakan Kedokteran.

Jakarta: Konsil Kedokteran Indonesia.

Menteri Kesehatan Republik Indonesia. (2005).

Permenkes Republik Indonesia No.1419/Menkes/Per/X/2005

Tentang Penyelenggaraan Praktik Dokter dan Dokter Gigi. Jakarta: Menteri Kesehatan Republik Indonesia.

Samil RS. (2011). Etika Kedokteran Indonesia. Jakarta: Yayasan Bina Pustaka Sarwono Prawirohardjo.
Guwandi J. (1996). Dokter, Pasien, dan Hukum. Jakarta: Balai Penerbit FKUI.

Konsil Kedokteran Indonesia. (2006). Keputusan Konsil

Kedokteran Indonesia

No.17/KKI/Kep/VIII/2006

Tentang Pedoman Penegakan

Disiplin Profesi Kedokteran.

Jakarta: Konsil Kedokteran

Indonesia.

Notoadmodjo, S. (2012). Metodologi Penelitian

Kesehatan.Jakarta: Rineka

Cipta.

Hatta, Gemala R. (2011). Pedoman Manajemen Informasi

Kesehatan di Sarana

Pelayanan Kesehatan. Jakarta: Univeristas Indonesia Press.

Menteri Kesehatan Republik Indonesia. (2008).

Permenkes Republik Indonesia No.290/Menkes/Per/III/2008

Tentang Persetujuan Tindakan Kedokteran. Jakarta: Menteri Kesehatan Republik Indonesia.

Widjaya, Lily. (2014). Manajemen informasi kesehatan 3

Analisis Kuantitatif dan kualitatif, Semester 7. Jakarta: Universitas Esa Unggul.

J.Guwandi. (2008). Informed Consent \& Informed Refusal, Jakarta: Fak. Kedokteran UI.

Brunner \& Suddarth. (2000). Keperawatan Medikal Bedah. Jakarta: EGC.

Sjamsuhidajat \& de jong. (2010). Buku Ajar Ilmu Bedah. Jakarta: EGC.

Sjamsuhidajat, R \& Wim, de Jong (ed). 2004. Buku Ajar Ilmu Bedah.Jakarta: EGC.

Naili, Sumarni. (2014). Studi Kelengkapan Pengisian

Persetujuan Tindakan Medik Di RSU Ajibarang Kabupaten Banyumas. Purwokerto.

Sugiarsi, S. (2016). Analisis Kelengkapan Pengisian

Formulir Persetujuan

Tindakan Kedokteran Kasus Bedah Mayor di RSUD 
Ambarawa. Rekam Medis, 10(1).

Herfiyanti, L. (2015). Kelengkapan

Informed Consent

Tindakan Bedah Menunjang
Akreditasi Jci Standar Hpk 6

Pasien Orthopedi. Jurnal

Manajemen Informasi

Kesehatan Indonesia (JMIKI), $3(2)$. 